\title{
PENGARUH IMBALAN, LINGKUNGAN KERJA, TERHADAP KINERJA PEGAWAI DAN KEPUASAN KERJA SEBAGAI VARIABEL INTERVENING PADA APARTEMEN BOTANICA JAKARTA
}

\author{
Guston Sitorus *) \\ *)Dosen Tetap Program S1 Jurusan Manajemen Fakultas Ekonomi Universitas Satya Negara Indonesia \\ mkb guston01@yahoo.com
}

\begin{abstract}
The objective of this research is to anlize and test the effect of rewards, work enviroment, and job satisfaction on performance. Performance is assumed to be significantly effected by the rewards, work enviroment, and job satisfaction that pertain in the organization. The causal study reported here aimed to examine the hypothesis. It was conducted through a survey in the Apartemen Botanica Jakarta a sample of 111 people randomly selected from the overall population of 135 employe. The data of each variable were collected separately by the respondens' filling in a questionnaire. The path technique was applied to analyze the data wich had been previously treated with the aggressive and coorelation procedure. The result proved that the employee performance was directly effected by the rewards, the work envoroment and job satisfaction was in turn, directly effected by rewards and work enviroment. The findings suggest that the variation of performance of the employee might have been effected by the rewards, the work enviroment, and the job satisfaction in the organization. This further implies the need take the variables of rewards, job satisfaction, and performance into the consideration in the strategic planning of the human resources development in the Apartemen Botanica Jakarta
\end{abstract}

Key words : Rewards, Work Enviroment, Job Satisfaction, Performance.

\section{Pendahuluan}

Faktor sumber daya manusia sampai saat ini masih diyakini sebagai penentu utama kesuksesan dalam setiap organisasi. Sumber daya manusia merupakan sumber daya aktif yang berperan mengoptimalkan dan mendayagunakan sumber daya-sumber daya yang lain agar bersinergi untuk mencapai tujuan organisasi. Walau sumber daya yang lain melimpah, seperti sarana-prasarana dan keuangan, jika tidak didukung oleh sumber daya manusia yang berkompeten akan sia-sia. Oleh karena itu, dalam upaya merwujudkan visi dan misinya, Apartemen Botanica membutuhkan sumber daya manusia yang kompeten, sehingga mampu mewujudkan kinerja yang unggul.

Dalam realitas, bukan sebuah pekerjaan yang mudah membangun sumber daya manusia atau pegawai yang mampu menunjukkan kinerja unggul. Dalam hubungan kinerja, kondisi rill di Apartemen Botanica Jakarta menunjukkan gejala yang kurang kondusif, yaitu kinerja pegawai yang masih belum maksimal. Indikasinya antara lain tampak dari hasil kerja yang kurang memenuhi standar atau target yang telah ditetapkan, tidak mampu melakukan terobosanterobosan penting yang diperlukan untuk memajukan Apartemen Botanica, dan suka menggunakan jam kerja atau fasilitas kantor untuk kepentingan pribadi. Dari sisi layanan yang diberikan, juga masih sering menuai kritik, dari pengunjung, baik itu menyangkut daya tanggap, pengetahuan yang dimiliki pegawai, maupun terkait dengan cara-cara dalam menanggapi keluhan pengunjung. 
Dalam mengurai kinerja para pegawai di Apartemen Botanica tersebut, tidak bisa hanya melihat dari satu sisi, tetapi juga perlu berpikir secara sistematik dalam konteks sebuah organisasi. Hal ini mengingat bahwa buruknya kinerja seseorang pegawai tidak berdiri sendiri, tetapi bersinggungan dengan faktor-faktor lain, baik itu faktor eksternal maupun internal. Salah satu faktor eksternal yang mempengaruhi kinerja adalah imbalan, sedangkan faktor internalnya dapat berupa lingkunan kerja dan kepuasan kerja.

Pertama, faktor eksternal yang terkait dengan imbalan. Faktor ini potensial memengaruhi kinerja karena imbalan yang diberikan organisasi secara rill bersentuhan langsung dengan kebutuhan pegawai, terutama kebutuhan fisiologis yang meliputi pangan, sandang, dan papan. Apabila imbalan yang diberikan kepada pegawai terbukti dapat memenuhi kebutuhan pegawai, maka hal itu akan menstimulasi pegawai untuk menunjukkan kinerja yang lebih baik. Apabila imbalan dimaknai secara luas, yakni mencakup imbalan ekstrinsik dan intrinsik, maka imbalan sangat efektif untuk membangun sikap dan perilaku positif seorang pegawai dalam bekerja termasuk untuk menumbuhkan kepuasan kerja. Jika dalam sebuah organisasi seorang pegawai mendapatkan imbalan finansial yang memadai, terbuka peluang bagi pertumbuhan diri dan pengembangan kecakapan, serta diberikan tanggung jawab yang cukup, maka sudah menjadi konsekuensi logis bagi seorang pegawai untuk mendapatkan rasa puas dalam bekerja. Lain halnya, jika dalam organisasi seorang pegawai tidak mendapatkan imblaan finansial yang memadai, tidak tersedia kesempatan untuk mengembangkan kecakapan, pertumbuhan pribadi yang terbatas, dan tanggung jawab yang minim, maka kecil kemungkinan bagi seorang pegawai dapat merasakan kepuasan dalam bekerja.

Optimisme ini sangat dibutuhkan dalam mencapai setiap keberhasilan, tidak terkecuali di lingkungan pekerjaan. Kondisi itu tidak saja akan mengarahkan individu untuk dapat menghasilkan kinerja yang lebih baik, tetapi juga dapat mendorong timbulnya rasa puas atas tugas atau pekerjaan yang dapat dituntaskan. Lain halnya jika individu tidak memiliki keyakinan yang kuat utuk dapat menyelesaikan tugas-tugas dan persoalan- persoalan yang dihadapi, maka akan menurunkan semangat hidup, sehingga berimplikasi terhadap tumbuhnya rasa malas dalam bekerja. Timbulnya keadaan seperti ini sudah dapat dipastikan akan mengakibatkan hasil kerja yang tidak sesuai standar, juga menjauhkan diri dalam mendapatkan rasa puas dalam bekerja.

Faktor internal lain yang memebrikan dampak terhadap kinerja yaitu kepuasan kerja. Kepuasan kerja menunjukkan perasaan senang yang dirasakan seseorang terhadap pekerjaan yang dilakukan. Perasaan senang dalam bekerja ini merupakan modal dasar yang harus dimiliki agar seseorang dapat menunjukkan totalitas dalam bekerja. Semangat bekerja juga akan tumbuh jika rasa senang dalam bekerja itu muncul. Dengan adanya perasaan- perasaan positif seperti itu, pegawai akan dapat menghasilkan kinerja yang lebi haik. Kondisi yang berbeda adalah pegawai tidak akan dapat menghasilkan kinerja yang memuaskan, jika tidak merasakan kepuasan dalam bekerja. Pegawai yang tidak puas dalam bekerja akan merasa gelisah dan banyak mengeluh, sehingga banyak kehilangan kosnentrasi dalam bekerja. Kondisi-kondisi emosional yang negatif seperti itu sangat menguras tenaga dan pikiran, sehingga memberikan dampak yang buruk terhadap hasil kinerjanya.

Berdasarkan uraian di atas, maka peneliti tertarik untuk meneliti secara ilmiah hal tersebut, sehingga dalam penelitian ini mengambil judul: Pengaruh Imbalan, Lingkungan Kerja, Terhadap Kinerja Pegawai dan Kepuasan Kerja sebagai Variabel Intervening pada Apartemen Botanica Jakarta.

\section{Tujuan Penelitian}


Penelitian ini bertujuan untuk mengkaji factor-faktor yang turut mempengaruhi Kinerja Pegawai pada Apartemen Botanica Jakarta yang meliputi Imbalan, Lingkungan Kerja, dan kepuasan kerja.

\section{Tinjauan Pustaka}

Kinerja adalah nilai dari seperangkat perilaku karyawan yang berkontribusi, baik secara positif atau negative terhadap pemenuhan tujuan organisasi. Kinerja ditentukan oleh tiga factor, yaitu 1) kinerja tugas (task force) dipengaruhi oleh rutinitas dan adaptasi, 2) perilaku kesetiaan atau komitmen (citizenship behavior) dipengaruhi oleh factor interpersonal dan organisasional termasuk imbalan, 3) perilaku produktif tandingan (counter productive behavior) dipengaruhi oleh factor deviasi sifat, factor deviasi produksi, factor deviasi politik, dan factor agresi personal termasuk kepuasan. Tingkat keberhasilan seseorang dalam menyelesaikan pekerjaannya disebut dengan istilah level of performance atau level kinerja.

Imbalan atau kompensasi memiliki makna serupa, yakni sebagai bentuk balas jasa yang diberikan kepada pegawai atas usahanya mencapai tujuan organisasi. Imbalan diberikan kepada seseorang dibangun dengan filsafat yang jelas dan tegas. Artinya sistem imbalan dibangun dengan sekurang-kurangnya mensyaratkan; imbalan yang layak layak dan adil; pengakuan atas arti penting setiap sumbangan pegawai bagi organisasi, dan paket kompensasi atas penawaran harus bersaing dalam bursa kerja eksternal untuk menarik dan mempertahankan pegawai yang cakap.

Imbalan atau penghargaan tinggi atas kualitas kerja dalam sistem imbalan akan mendorong pegawai berusaha menunjukkan kinerja terbaiknya, yang dicapai melalui serangkaian kegiatan yang dilaksanakan secara efisien dan efektif dalam rangka mencapai tujuan organisasi yang tercermin dalam loyalitas, keandalan, kecakapan berkomunikasi, ketrampilan intrapersonal, dan inisiatif. Dengan demikian dapat diduga bahwa imbalan memiliki pengaruh langsung terhadap kinerja pegawai.

Disamping itu imbalan sangat penting bagi kehidupan seseorang dalam bekerja. Imbalan dalam artian ini merupakan balas jasa yang diberikan kepada pegawai sebagai sarana untuk mencapai tujuan organisasi. Berbagai aspek imbalan terselubung apabila dipersepsikan dan dirasakan memadai oleh individu akan mendatangkan kepuasan, yakni suatu perasaan menyenangkan yang muncul sebagai akibat dari penilaian kerja atau pengalaman kerja. Dengan demikian dapat diduga bahwa imbalan berpengaruh langsung terhadap kepuasaan kerja pegawai.

Lingkungan kerja merupakan segala sesuatu yang ada disekitar karyawan pada saat bekerja, baik yang berbentuk fisik ataupun non fisik, langsung atau tidak langsung, yang dapat mempengaruhi dirinya dan pekerjaanya saat bekerja.Lingkungan kerja meliputi ruang, udara, suhu, cahaya, kebisingan, alat-alat, bahan-bahan, tata letak fisik, dan hubungan rekan kerja serta kualitas dari semuanya mempunyai dampak positif terhadap kinerja pegawai, artinya jika keseluruhan sarana dan prasarana yang ada di sekitar karyawan yang sedang melakukan pekerjaan itu sendiri kondusif maka kinerja karyawajn akan meningkat. Dengan demikian, dapat diduga bahwa lingkungan kerja memiliki pengaruh langsung terhadap kinerja pegawai.

Di samping itu lingkungan kerja juga merupakan salah satu factor yang berperan penting dan strategis dalam kelangsungan hidup suatu perusahaan. Lingkungan kerja dapat mendorong semangat kerja pegawai dan sekaligus membuat kepuasan kerja pegawai meningkat sehingga tujuan perusahaan dapat tercapai secara efektif dan efisien. Oleh sebab itu lingkungan kerja suatu organisasi perusahaan dituntut untuk selalu kondusif yang mampu memuaskan pegawai dalam bekerja sehingga diperoleh karyawan yang tidak hanya mampu bekerja akan tetapi juga bersedia bekerja ke arah pencapaian tujuan perusahaan. Dengan demikian, dapat diduga bahwa lingkungan kerja memiliki pengaruh langsung terhadap kepuasan kerja.

Kepuasan kerja adalah sebagai keadaan emosi yang positif dari mengevaluasi pengalaman kerja seseorang. Beberapa hal-hal utama yang mempengaruhi kepuasan kerja bisa 
dikelompokkan mejadi tiga. Pertama, faktor organisasi yang teridir atas gaji (imbalan), kesempatan untuk promosi, pekerjaan itu sendiri, kondisi kerja (lingkungan kerja), dan prosedur organisasi. Kedua, faktor kelompok yang teridiri atas atasan (supervisor, pimpinan, manajer) dan rekan kerja. Ketiga, faktor individu yang terdiri atas kebutuhan-kebutuhan pribadi dan aspirasinya.

Dalam bekerja seseorang membutuhkan perasaan menyenangkan, terutama yang muncul dari penilaian kerja atau pengalaman kerja yang terkait dengan pekerjaan itu sendiri, Perasaan menyenangkan tersebut akan membuat seseorang tenang dan nyaman dalam bekerja, sehingga memungkinkan dirinya bekerja dengan loyal, handal, cakap dalam komunikasi, terampil secara interpersonal dan kaya inisiatif. Kepuasan kerja karyawan merupakan hal yang bersifat individual tentang perasaan seseorang terhadap pekerjaannya. Kepuasan kerja merupakan salah satu faktor yang dapat mempengaruhi kinerja. Semua ini diperlukan untuk membangun kinerja sebagai cerminan hasil kerja yang unggul yang dicapai melalui serangkaian kegiatan yang dilaksanakan secara efisien dan efektif dalam rangka mencapai tujuan organisasi. Dalam tataran ini terlihat bahwa kepuasan kerja diperlukan untuk membangun kinerja. Dengan demikian, dapat diduga bahwa kepuasan kerja memiliki pengaruh langsung terhadap kinerja pegawai.

\section{Metodologi}

Penelitian ini bertujuan untuk menganalisis pengaruh langsung imbalan terhadap kinerja pegawai, lingkungan terhadap kinerja pegawai, imbalan terhadap kepuasan kerja, lingkungan kerja terhadap kepuasan kerja, dan kepuasan kerja terhadap kinerja pegawai.

Tempat penelitian ini dilaksanakan di Apartemen Botanica Jakarta. Waktu penelitan ini dilaksanakan September 2016 sampai dengan Pebruari 2017. Metode penelitian yang digunakan dalam penelitian ini adalah metode penelitian deskriptif dengan survey dengan menggunakan instrument kuesioner. Sesuai metodologi penelitian yang digunakan dalam penelitian ini, maka teknik analisis datanya adalah analisis jalur (path analysis).

Populasi target (target population) dalam penelitian ini adalah seluruh pegawai Apartemen Botanica. Sedangkan populasi terjangkau (accessible population) sebagai kerangka sampel adalah 153 orang pegawai Apartemen Botanica Jakarta.

Untuk populasi 153 orang, menurut ketentuan Tabel Krejcie \& Morgan, diperlukan sampel minimal 111 pegawai. Berdasarkan ketentuan tersebut, maka sampel penelitian ini ditetapkan 111 pegawai. Pengambilan sampel dilakukan secara simple random sapling.

\section{Hasil Penelitian dan Pembahasan}

Berikut ini diuraikan hasil penelitian sebagai berikut:

\section{Pengaruh Langsung Positif Imbalan $\left(X_{1}\right)$ terhadap Kinerja Pegawai (Y)}

Untuk membuktikan Hipotesis bahwa Imbalan $\left(\mathrm{X}_{1}\right)$ berpengaruh langsung terhadap Kinerja Pegawai (Y). dengan menggunakan analisis jalur diperoleh koefisien jalur $\mathrm{P}_{\mathrm{y} 1}$ sebesar 0,12 dengan $t_{\text {hitung }}$ sebesar 2,31, dan pada titik kritik $\alpha=0,05$ diperoleh $t_{\text {tabel }}$ sebesar 1,658., maka $\mathrm{H}_{0}$ ditolak dan $\mathrm{H}_{1}$ diterima. Sehingga dapat ditafsirkan bahwa Imbalan $\left(\mathrm{X}_{1}\right)$ berpengaruh langsung positif terhadap Kinerja Pegawai (Y).

Hasil penelitian ini menyimpulkan bahwa Imbalan berpengaruh langsung positif terhadap Kinerja pegawai, dengan demikian implikasinya adalah bahwa dalam meningkatkan kinerja pegawai perlu memberikan imbalan yang semakin meningkat. Pemberian imbalan yang semakin meningkat ini dapat dilakukan dengan peningkatan upah/gaji, tunjangan, Insentif, penghasilan tambahan, lembur, dan tunjangan lainnya. Dengan melakukan berbagai 
peningkatan dan perbaikan imbalan ini menjadi lebih baik, maka akan terjadi peningkatan kinerja pegawai Apartemen Botanica Jakarta.

\section{Pengaruh Langsung Positif Lingkungan Kerja $\left(\mathrm{X}_{2}\right)$ terhadap Kinerja Pegawai (Y)}

Untuk membuktikan Hipotesis bahwa Lingkungan Kerja $\left(\mathrm{X}_{2}\right)$ berpengaruh langsung positif terhadap Kinerja Pegawai (Y), dengan menggunakan analisis jalur diperoleh koefisien jalur $\mathrm{P}_{\mathrm{y} 2}$ sebesar 0,38 dengan $\mathrm{t}_{\text {hitung }}$ sebesar 6,53, dan pada titik kritik $\alpha=0,05$ diperoleh $t_{\text {tabel }}$ sebesar 1,658 , karena $t_{\text {hitung }}>t_{\text {tabel }}$ maka $H_{0}$ ditolak dan $H_{1}$ diterima. Sehingga dapat ditafsirkan bahwa Lingkungan Kerja $\left(\mathrm{X}_{2}\right)$ berpengaruh langsung positif terhadap Kinerja Pegawai (Y).

Hasil penelitian ini menyimpulkan bahwa Lingkungan Kerja berpengaruh langsung positif terhadap Kinerja Pegawai, dengan demikian implikasinya adalah bahwa dalam meningkatkan kinerja pegawai perlu ditingkatkan kualitas lingkungan kerja. Peningkatan kualitas lingkungan kerja dapat dilakukan dengan meningkatkan kualitas lampu penerangan ruang kerja, membuat suhu rauang kerja yang sejuk. Sirkulasi udara yang bagus, terhindar dari suara bising, membuat warna ruangan yang terang, dan membuat lay out yang efisien. Dengan dilaksakannya lingkungannya kerja yang semakin berkualitas ini maka akan dapat meningkatkan kinerja pegawai Apartemen Botanica Jakarta.

\section{Pengaruh Langsung Positif Kepuasan Kerja $\left(\mathrm{X}_{3}\right)$ terhadap Kinerja Pegawai $(\mathrm{Y})$}

Untuk membuktikan Hipotesis bahwa Kepuasan Kerja $\left(\mathrm{X}_{3}\right)$ berpengaruh langsung terhadap Kinerja Pegawai (Y). dengan menggunakan analisis jalur diperoleh koefisien jalur $\mathrm{P}_{\mathrm{y} 3}$ sebesar 0,17 dengan $\mathrm{t}_{\text {hitung }}$ sebesar 3,51, dan pada titik kritik, $\alpha=0,05$ diperoleh $\mathrm{t}_{\text {tabel }}$ sebesar 1,658, karena $t_{\text {hitung }}>\mathrm{t}_{\text {tabel }}$ maka $\mathrm{H}_{0}$ ditolak dan $\mathrm{H}_{1}$ diterima. Sehingga dapat ditafsirkan bahwa Kepuasan Kerja $\left(\mathrm{X}_{3}\right)$ berpengaruh langsung positif terhadap Kinerja Pegawai (Y).

Hasil penelitian ini menyimpulkan bahwa Kepuasan Kerja berpengaruh langsung positif terhadap Kinerja Pegawai, dengan demikian implikasinya adalah untuk meningkatkan kinerja pegawai maka perlu ditingkatkan kepuasan kerja pegawai. Kepuasan kerja ini dapat ditingkatkan dengan memperhatikan berbagai aspek yang berhubungan dengan kehidupan pegawai dalam berorganisasi atau bekerja, yaitu memperbaiki tingkat upah, memberikan kesempatan untuk dipromosikan, memiliki pemimpin yang jujur, cerdas, adil, dan sebagainya. Memiliki rekan kerja yang saling pengertian dan rasa empati yang tinggi, termasuk juga beban kerja pegawai itu sendiri yang tidak terlalu berat dan tidak terlalu sulit. Dengan memperhatikan atau bahkan meningkatkan berbagai hal yang berhubungan dengan kepuasan kerja pegawai maka akan dapat meningkatkan kinerja pegawai Apartemen Botanica Jakarta.

\section{Pengaruh Langsung Positif Imbalan $\left(X_{1}\right)$ terhadap Kepuasan Kerja $\left(X_{3}\right)$}

Untuk membuktikan Hipotesis bahwa Imbalan $\left(\mathrm{X}_{1}\right)$ berpengaruh langsung terhadap Kepuasan Kerja $\left(\mathrm{X}_{3}\right)$. dengan menggunakan analisis jalur diperoleh koefisien jalur $\mathrm{P}_{31}$

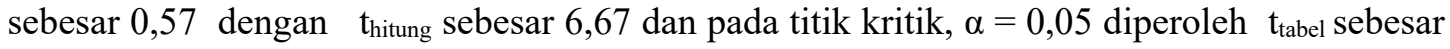
1,658, karena $t_{\text {hitung }}>t_{\text {tabel }}$ maka $\mathrm{H}_{0}$ ditolak dan $\mathrm{H}_{1}$ diterima. Sehingga dapat ditafsirkan bahwa Imbalan $\left(\mathrm{X}_{1}\right)$ berpengaruh langsung positif terhadap Kepuasa Kerja $\left(X_{3}\right)$.

Hasil penelitian ini menyimpulkan bahwa Imbalan berpengaruh langsung positif terhadap Kepuasan Kerja, dengan demikian implikasinya adalah untuk meningkatkan Kepuasan Kerja pegawai maka perlu dilakukan memberikan imbalan yang semakin meningkat, yaitu berupa peningkatan upah/gaji, tunjangan, Insentif, penghasilan tambahan, 
lembur, dan tunjangan lainnya. Dengan melakukan berbagai peningkatan dan perbaikan imbalan ini menjadi lebih baik, maka akan terjadi peningkatan Kepuasan Kerja pegawai Apartemen Botanica Jakarta.

\section{Pengaruh Langsung Positif Lingkungan Kerja $\left(X_{2}\right)$ terhadap Kepuasan Kerja $\left(X_{3}\right)$}

Untuk membuktikan Hipotesis bahwa Lingkungan Kerja $\left(\mathrm{X}_{2}\right)$ berpengaruh langsung terhadap Kepuasan Kerja $\left(\mathrm{X}_{3}\right)$. dengan menggunakan analisis jalur diperoleh koefisien jalur $\mathrm{P}_{32}$ sebesar 0,40 dengan $t_{\text {hitung }}$ sebesar 3,65, dan pada titik kritik, $\alpha=0,05$ diperoleh $t_{\text {tabel }}$ sebesar 1,658, karena $t_{\text {hitung }}>t_{\text {tabel }}$ maka $\mathrm{H}_{0}$ ditolak dan $\mathrm{H}_{1}$ diterima. Sehingga dapat ditafsirkan bahwa Lingkungan Kerja $\left(\mathrm{X}_{2}\right)$ berpengaruh langsung positif terhadap Kepuasan $\operatorname{Kerja}\left(X_{3}\right)$.

Hasil penelitian ini menyimpulkan bahwa Lingkungan Kerja berpengaruh langsung positif terhadap Kepuasan Kerja, dengan demikian implikasinya adalah bahwa dalam meningkatkan kinerja pegawai perlu ditingkatkan kualitas lingkungan kerja. Yaitu berupa peningkatkan kualitas lampu penerangan ruang kerja, membuat suhu ruang kerja yang sejuk. sirkulasi udara yang bagus, terhindar dari suara bising, membuat warna ruangan yang terang, dan membuat lay out yang efisien. Dengan dilaksakannya lingkungannya kerja yang semakin berkualitas ini maka akan dapat meningkatkan Kepuasan Kerja pegawai Apartemen Botanica jakarta

\section{Kesimpulan}

Berdasarkan hasil penelitian dan pembahasan yang telah diuraikan di atas, maka kesimpulan penelitian ini adalah sebagai berikut:

1. Imbalan berpengaruh langsung positif terhadap Kinerja Pegawai. Temuan ini memberikan makna bahwa dengan adanya Imbalan yang semakin baik akan dapat meningkatkan Kinerja Pegawai Apartemen Botanica Jakarta.

2. Lingkungan Kerja berpengaruh langsung positif terhadap Kinerja Pegawai. Temuan ini memberikan makna bahwa dengan adanya peningkatan kualitas lingungan kerja maka akan dapat meningkatkan Kinerja Pegawai Apartemen Botanica Jakarta.

3. Kepuasan Kerja berpengaruh langsung positif terhadap Kinerja Pegawai. Temuan ini memberikan makna bahwa dengan meningkatkan Kepuasan Kerja pegawai maka akan dapat meningkatkan Kinerja Pegawai Apartemen Botanica Jakarta.

4. Imbalan berpengaruh langsung positif terhadap Kepuasan Kerja Pegawai. Temuan ini memberikan makna bahwa dengan adanya pemberian imbalan yang semakin meningkat maka akan dapat meningkatkan Kepuasan Kerja Pegawai Apartemen Botanica Jakarta.

5. Lingkungan Kerja berpengaruh langsung positif terhadap Kepuasan Kerja Pegawai. Temuan ini memberikan makna bahwa dengan adanya peningkatan kualitas lingungan kerja maka akan dapat meningkatkan Kepuasan Kerja Pegawai Apartemen Botanica Jakarta.

\section{Saran}

Berdasarkan pada kesimpulan dan implikasi penelitian di atas, maka peneliti akan memberikan beberapa saran perbaikan yang berkaitan dengan peningkatan kinerja pegawai Apartemen Botanica Jakarta sebagai berikut:

1. Dalam rangka meningkatkan Kinerja Pegawai pihak manajemen Apartemen Botanica Jakarta sebaiknya memberikan Imbalan yang lebih baik lagi artinya terjadi peningkatan kuantitas dan kualitas imbalan, yaitu memberikan gaji/upah, tunjangan, atau unsur-unsur lainnya yang dapat menambah imbalan pegawai itu sendiri. 
2. Dalam rangka meningkatkan Kinerja Pegawai maka disarankan agar pihak manajemen Apartemen Botanica Jakarta meningkatkan kualitas lingkungan kerja, yaitu dengan meningkatkan kualiats lingkungan kerja pegawai, seperti membuat suhu ruangan bersih, udara ruangan sejuk, sirkulasi ruangan bagus, dan sinar lampu ruangan terang.

3. Dalam rangka meningkatkan Kinerja Pegawai maka disarankan pihak manajemen Apartemen Botanica Jakarta agar meningkatkan kepuasan kerja pegawai, yaitu dengan memberikan upah yang semakin meningkat, memberikan fasilitas kesehatan, fasilitas transportasi, dan lain sebagainya.

\section{DAFTAR PUSTAKA}

Ardana, Komang., Ni Wayan Mujiati dan I Wayan Mudiartha Utama. Manajemen Sumber Daya Manusia. Yogyakarta: Graha Ilmu, 2012.

Chen, Li Yueh. "Examining the Effect of Organization Culture and Leadership Behaviours on Organizational Commitment, Job Statisfaction, and Job Performance at Small and MidleSized Firms of Taiwan". The Jurnal of American Academy of Business. Vol. 5, No. 1. 2004.

Colquitt Jason A., Jeffrey A. LePine \& Michael j. Wesson, Organizational Behaviour: Inproving Performance and Commitment in the Workplace, New York: Mc. Graw Hill, 2009.

Judge,Timothy A. Judge, et al. " The Job Statisfaction-performance relationship: a qualitative and quantitave review," Psychological Bulettin, Vol. 127 No.3, 2001.

Mangkunegara, Anwar Prabu. Evaluasi Kinerja SDM. Jakarta: Refika Aditama, 2009.

Malthis, Robert L. dan John H. Jackson, Human Resource Management, 13 ${ }^{\text {th }}$, South-Western: Cengage Learning, 2011.

Nitisemito, Alex S, Manajemen Personalia, cetakan ke empat, Jakarta: Ghalia Indonesia, 1983.

Rivai, Veithzal. Manajemen Sumber Daya Manusia untuk perusahaan, Jakarta: PT. Raja Grafindo Persada, 2004.

Robbins, Sthephen P., Perilaku Organisasi: Konsep, Kontroversi, Aplikasi, Jakarta: Prenhalindo, 2001.

Siagian, Sondang P. Manajemen Sumber Daya Manusia, Edisi Kelima Belas, Jakarta: Bumi Aksara, 2015.

Sianipar J.P., Perencanaan Peningkatan Kinerja, Bahan Diklat Spama, Jakarta, Lembaga Administrasi Negara (LAN), 1999.

Sutrisno, Edy, Budaya Organisasi, Jakarta: Grafindo, 2015.

Thoha Miftah. Perilaku Organisasi Konsep Dasar dan Aplikasinya, Jakarta: PT. Grafindo Persada, 1999.

Uus Md Fadli et. al. "Pengaruh Kepuasan Kerja terhadap Kinerja Dosen Universitas Singaperbangsa Karawang,” Jurnal Manajemen Vol.09 No.2 Januari 2012. 
Wahab, Abdul Azis. Anatomi Organisasi dan Kepemimpinan Pendidikan, Telaah Terhadap Organisasi dan Pengelolaan Organisasi Pendidikan. Bandung: Alfabeta, 2008.

Wibowo, Manajemen Kinerja, Jakarta: PT. Raja Grafindo Persada, 2014.

Werther, William B. dan Keith Davis, Human Resources and Personnel Management, New York: McGraw-Hill, 1996. 